\title{
A non-reductive science of personality, character, and well-being must take the person's worldview into account
}

\author{
Artur Nilsson * \\ Department of Psychology, Lund University, Lund, Sweden \\ *Correspondence: artur.nilsson@psy.lu.se \\ Edited by: \\ Danilo Garcia, University of Gothenburg, Sweden \\ Reviewed by: \\ Henrik Anckarsäter, University of Gothenburg, Sweden
}

Keywords: worldview, meaning-making, non-reductive materialism, personality, character, well-being

In his foundational work for personality psychology, Allport (1927, 1937) distinguished personality from character. Personality was, on Allport's account, a descriptive concept referring to a psychophysical structure, whereas character was personality evaluated in accordance with moral norms. When he introduced the paradigmatic "lexical" method of deriving personality trait terms from the dictionary, he therefore sought to exclude all trait terms with ostensive normative content. This approach had a profound effect upon the field, and researchers are still today working on how to optimally purge personality of normative content (e.g., Bäckström et al., 2009; Pettersson and Turkheimer, 2010). Its appropriateness as a paradigm for the entire field of personality psychology can, however, be questioned (Kristjánsson, 2012; Nilsson, 2014). It is plausible that some personality characteristics particularly relevant to psychic illness, human flourishing, and moral behavior are intrinsically valueladen (Cloninger et al., 1993; Cawley et al., 2000; Peterson and Seligman, 2004).

I will focus on Cloninger's approach here, because he has, in addition to introducing an influential model of character, discussed the philosophical foundations of the study of character and well-being. For Cloninger (2004), character is not only value-laden; it refers to uniquely human aspects of personality representing "what people make of themselves intentionally" (p. 44), as contrasted with their animalistic temperament. He wants the science of character and well-being to transcend the dichotomy between materialist reductionism and
Cartesian dualism, by taking the person's consciousness, agency, and processes of self-growth seriously while integrating this with knowledge about the human physical and biological constitution. Although I agree with this idea of having a non-reductive psychological science, I disagree with Cloninger about what it entails. I will therefore review Cloninger's (2004) approach from a philosophical perspective, in a critical and, hopefully, constructive way. I will defend a notion of non-reductive psychology based upon contemporary academic philosophy and argue that Cloninger's approach is not genuinely non-reductive. I will suggest that a non-reductive psychological science must take the person's worldview into account and argue that Cloninger's approach limits our understanding of human psychology by not considering the role of worldviews in the development of character and well-being.

\section{NON-REDUCTIVE MATERIALISM}

Today, philosophers who seek to transcend the dichotomy between reductive materialism and Cartesian dualism generally adopt some version of non-reductive materialism (Davidson, 1963, 1970; Fodor, 1974; Searle, 1983, 1992; Chalmers, 1996), claiming that although all mental states and events are causally realized in the brain, there is not a particular type of brain state corresponding to each type of mental state. The reason for this is that we identify and individuate mental states in terms of a folk psychological language of "attitudes," "beliefs," "desires," "emotions," "goals," etc., which is holistic, insofar as it describes mental states as partly con- stituted by their relations to each other and their neurophysiological realization and behavioral manifestation as therefore dependent upon the entire network of mental states. In other words, on nonreductive materialism, no particular belief, goal, desire, or other intentional state, let alone a more complex folk psychological concept such as "personality," "character," or "well-being," can even in principle be isolated and reduced to neurophysiology or behavior, and these irreducible folk psychological concepts are crucial for understanding human psychology.

A key implication of non-reductive materialism is that human experiences and actions are imbued with meaning; to treat human beings as persons, rather than mere mechanical systems or animals, is to treat them as linguistic beings, who construct reasons and act upon them (Hacker, 2007), partly driven by needs to create and sustain meanings and to assuage fears and anxieties fueled by their uniquely human awareness of their existential condition (Nilsson, 2013). Although meaning-making is today studied in such different fields as the psychology of adaptation and wellbeing (Janoff-Bulman, 1992; Wong, 2012), social psychology (Greenberg et al., 1986; Heine et al., 2006), and neuropsychology (Gazzaniga, 2005), researchers rarely take into consideration the fact that meaning is constructed within a worldview - the person's most basic beliefs, values, constructs, and scripts for understanding, evaluating, and acting upon reality, which ground the network within which more specific beliefs, goals, intentions, etc., are embedded. A person necessarily lives through 
a worldview-s/he can only, for example, act, morally or immorally, upon a worldview, and experience well-being, in its distinctly human form, through a worldview. A non-reductive psychological science must therefore treat the person's worldview as an aspect of personality in its own right, not reducible to behavioral or mental regularities (i.e., traits; Nilsson, 2014). Although personalists (Allport, 1937; Stern, 1938; Mounier, 1952; Lamiell, 1987), narrative psychologists (Tomkins, 1965, 1979; McAdams, 1992, 2008), and construct psychologists (Kelly, 1955; Little, 2005) have contributed to such an endeavor, worldviews do not receive the attention they deserve in contemporary psychology (Koltko-Rivera, 2004; Nilsson, 2013, 2014).

\section{CLONINGER'S TRANSCENDENTALISM}

Cloninger's (2004) approach instead merges elements of folk spirituality (cf. Forman, 2004), Eastern thought, Hegelian metaphysics, and quantum physics. He suggests that a person's consciousness can be developed, through a process catalyzed by meditation, reflection, and contemplation, toward increasing self-awareness, wisdom, goodness, and well-being. In the final, self-transcendent stage, the person is freed of all "dualistic" thought of body, mind, and spirit as separate and recognizes that "the individual mind is like a node in a universal Internet of consciousness" (p. 36), thereby attaining "coherence" of body, mind, and spirit, unconditional well-being, potential access to other minds, and "direct self-aware perception of what is real and true without misunderstanding as a result of preconceptions, prejudices, fears, desires, and conflicts" (p. 325). Cloninger (2004) also draws parallels between self-transcendent consciousness and quantum phenomena, including the impossibility of precisely determining the state and location of quantum particles ("non-locality") and the Higgs field within which particles acquire mass, and he claims, furthermore, that the unpredictability ("non-causality") of quantum physical events is "another way of talking about freedom" (p. 73) and that "the thought of gifted people involves intuitive leaps or quantum jumps, not deductive algorithms" (p. 65; cf. Capra, 1975).
Cloninger (2004, p. 317) makes clear that what he is proposing is not just a psychological theory, but also a philosophy of science:

The science of well-being is founded on the understanding that there is an indissoluble unity to all that is or can be. The universal unity of being is recognized widely as an empirical fact, as well as an essential organizing principle for any adequate science [..] the universal unity of being is the only viewpoint consistent with any coherent and testable science.

This passage is puzzling insofar as it describes the postulated unity of being both as empirical fact, which implies that it is open to empirical refutation, and as essential organizing principle constitutive of research in this area, which implies that it is, in Quine's (1953) terminology, close to the center of the scientific field and therefore not easily changed. Given that Cloninger (2004) suggests that recognition of the unity of being-thesis is ultimately intuitive and not amenable to rational argumentation or objective test, and that its critics lack self-awareness, this thesis is more properly treated as a presupposition and interpretive framework than as an empirical fact (Popper, 1959).

But whether this is an appropriate, nonreductive foundation for the study of persons is questionable. On the non-reductive account I am proposing, what is essential is that we take the person's subjective experiences and their meanings seriously, in psychological terms, treating them as real and irreducible; not that we assume that special forms of experience convey true insight into the nature of reality. One problem with Cloninger's approach is precisely that it does not give meaningmaking the role that it deserves in personality measurement and explanation of experience and action. Cloninger (2004) offers parallels to quantum physics rather than an account of reason-based explanation (Davidson, 1963; Searle, 1983) and Cloninger et al. (1993) measure character with traditional trait-type items which focus on typical behaviors and experiences, rather than worldview-type items which ask persons about their most basic beliefs, values, goals, and so on (Nilsson, 2014). Cloninger's use of quantum physics to describe the mind is, furthermore, whether interpreted as an "analogy" (p. 65) or as an explanation of "actual" processes underlying self-aware consciousness (p. 328), difficult to reconcile with non-reductive materialism. Although it is conceivable that the hitherto unidentified mechanisms through which the brain causes consciousness, agency, and certain qualitative feels operate at the quantum level (Chalmers, 1996; Searle, 1997), the folk psychological concepts that render our experiences and actions meaningful and agentic are, because of their logical holism, as irreducible to quantum physics as to classical physics, and we have little reason to assume that the causes of conscious experiences are isomorphic with their qualitative feels (Stenger, 1993; cf. Brown et al., 2013). Similar to this, Cloninger's (p. 38) invocation of Allport's definition of personality as a "psychophysical system" is inconsistent with nonreductive materialism, insofar as it is understood as implying that personality can be reduced to a neuro-physiological causal system (Nilsson, 2013). Finally, the Hegelian monist metaphysics Cloninger (2004) draws upon is rejected today even by Hegelians. For example, Pippin (1989, p. 4) - one of several philosophers reinterpreting Hegel in non-metaphysical terms in order to rehabilitate his philosophythinks that the "metaphysical monist or speculative, contradiction-embracing logician [..] is not the historically influential Hegel."

\section{IMPLICATIONS FOR RESEARCH}

Cloninger et al. (1993) model divides character into: (1) self-directedness, or agency, which incorporates acting deliberatively on personal goals and values, taking responsibility for actions, and developing resources for goal pursuit and self-acceptance, (2) cooperativeness, or communion, which incorporates compassion, empathy, helpfulness, acceptance of others, and acting on moral principles rather than self-interest, and (3) self-transcendence, which incorporates a sense of unity underlying the universe and connecting the self with the world around it, intuitive apprehension of relationships that cannot be explained rationally or observed objectively, and experiences of flow, absorption, and selfforgetfulness. These aspects of character 
correspond, respectively, to the person's relation to the self, to others, and to the universe. As such, they undoubtedly refer to basic aspects of our intentional engagement with the world. But the model does not take different worldviews into account. Self-transcendence, in particular, appears conflated with spiritual selftranscendence-that is, self-transcendence through spirituality. Self-transcendence, in a more general sense, can be understood as the pursuit of meaning and identity through participation in, and selfless contribution to, something larger than the self, whether this is a divine or spiritual reality, a community of persons or sentient beings, or an ideological ideal (Schwartz, 1992; MacDonald et al., 1998; Koltko-Rivera, 2004). It requires only that the person is connected to the outside world through intentional directedness at, and engagement with, that world; it does not require an actual physical or spiritual connection between the person and that toward which s/he directs him-/herself.

More generally, I suggest that character can be understood in terms of the interaction between the three proposed dimensions and the person's worldview, and that researchers therefore need to investigate how different worldviews facilitate and inhibit the development of character. Because character is an intrinsically normative concept, what counts as character is partly an empirical question-character is what turns out to produce desirable psychological, moral, and social consequences. We might ask, for example, if, and if so how, different worldviews can be reconciled with ethical self-transcendence, selfless love, genuine happiness, tolerance, creativity, autonomy, and experiences of wonder, beauty, and awe. It is, I suggest, unlikely that there is one ultimate path of character development suitable for all persons. Cloninger's (2004, p. 29) own observation that "outstanding exponents of positive philosophy have often had limited success in helping their followers develop coherence" is true, I suggest, partly because neither worldview nor the development of character and well-being is a one-size-fits-all. By considering the full potential range of personalities emerging from the diversity of human worldviews, we can, I contend, better understand and encourage the development of character and well-being, thus potentially harnessing the full positive potentials of humanity for cultural and social progress (cf. Cloninger, 2004, 2008, 2013).

\section{REFERENCES}

Allport, G. W. (1927). Concepts of trait and personality. Psychol. Bull. 24, 284-293. doi: 10.1037/h0073629

Allport, G. W. (1937). Personality: A Psychological Interpretation. New York, NY: Holt, Rinehart \& Winston.

Bäckström, M., Björklund, F., and Larsson, M. R. (2009). Five-factor inventories have a major higher order factor related to social desirability which can be reduced by framing items neutrally. J. Res. Pers. 43, 335-344. doi: 10.1016/j.jrp.2008.12.013

Brown, N. J. L., Sokal, A. D., and Friedman, H. L. (2013). The complex dynamics of wishful thinking: the critical positivity ratio. Am. Psychol. 68, 801-813. doi: 10.1037/a0032850

Capra, F. (1975). The Tao of Physics. Boston, MA: Shambhala publications.

Cawley, M. J., Martin, J. E., and Johnson, J. A. (2000). A virtues approach to personality. Pers. Individ. Dif. 28, 997-1013. doi: 10.1016/S01918869(99)00207-X

Chalmers, D. (1996). The Conscious Mind: In Search of a Fundamental Theory. New York, NY: Oxford University Press.

Cloninger, C. R. (2008). On well-being: current research trends and future directions. Mens Sana Monogr. 6, 3-9. doi: 10.4103/0973-1229.40564

Cloninger, C. R. (2013). What makes people healthy, happy, and fulfilled in the face of current world challenges? Mens Sana Monogr. 11, 16-24. doi: 10.4103/0973-1229.109288

Cloninger, C. R., Svrakic, D. M., and Przybeck, T. R. A. (1993). A psychobiological model of temperament and character. Arch. Gen. Psychiatry 50, 975-990. doi: 10.1001/archpsyc.1993.01820240059008

Cloninger, R. C. (2004). Feeling Good: The Science of Well-Being. New York, NY: Oxford University Press.

Davidson, D. (1963). Actions, reasons, and causes. J. Philos. 60, 685-700. Reprinted in Davidson, D. (2001). Essays on Actions and Events, 2nd $E d n$. New York, NY: Oxford University Press. doi: $10.2307 / 2023177$

Davidson, D. (1970). "Mental events," in Experience and Theory, eds L. Foster and J. W. Swanson (London: Duckworth), 79-101. Reprinted in Davidson, D. (2001). Essays on Actions and Events, 2nd Edn. New York, NY: Oxford University Press.

Fodor, J. (1974). Special sciences: Or the disunity of science as a working hypothesis. Synthese 28, 97-115. Reprinted in Emergence: Contemporary Readings in Philosophy and Science, eds M. A. Bedau and P. Humphreys (Cambridge: MIT Press), 395-410. doi: 10.7551/mitpress/9780262026215.003.0026

Forman, R. K. C. (2004). Grassroots Spirituality: What it is, Why it is Here, Where it is Going. Charlottesville, VA: Imprint Academic.

Gazzaniga, M. S. (2005). Forty-five years of split-brain research and still going strong. Nat. Rev. Neurosci. 6, 653-659. doi: 10.1038/nrn1723
Greenberg, J., Pyszczynski, T., and Solomon, S. (1986). "The causes and consequences of a need for selfesteem: a terror management theory," in Public Self and Private Self, ed R. F. Baumeister (New York, NY: Springer-Verlag), 189-212.

Hacker, P. (2007). Human Nature: The Categorical Framework. Oxford: Blackwell publishing.

Heine, S. J., Proulx, T., and Vohs, K. D. (2006). The Meaning Maintenance Model: on the coherence of social motivations. Pers. Soc. Psychol. Rev. 10, 88-110. doi: 10.1207/s15327957pspr1002_1

Janoff-Bulman, R. (1992). Shattered Assumptions: Towards a New Psychology of Trauma. New York, NY: Free Press.

Kelly, G. (1955). The Psychology of Personal Constructs. Vol. 1. New York, NY: W. W. Norton.

Koltko-Rivera, M. E. (2004). The psychology of worldviews. Rev. Gen. Psychol. 1, 3-58. doi: 10.1037/1089-2680.8.1.3

Kristjánsson, K. (2012). Selfhood, morality, and the five-factor model of personality. Theory Psychol. 22, 591-606. doi: 10.1177/0959354311431193

Lamiell, J. T. (1987).The Psychology of Personality: An Epistemological Inquiry. New York, NY: Columbia University Press.

Little, B. R. (2005). Personality science and personal projects: six impossible things before breakfast. J. Res. Pers. 39. 4-21. doi: 10.1016/j.jrp.2004. 09.003

MacDonald, M. J., Wong, P. T. P., and Gingras, D. T. (1998). "Meaning-in-life measures and development of a brief version of the personal meaning profile," in The Human Quest for Meaning: A Handbook of Psychological Research and Clinical Applications, eds P. T. Wong and P. S. Fry (London: Routledge), 357-382.

McAdams, D. P. (1992). The five-factor model in personality: a critical appraisal. J. Pers. 60, 329-361. doi: 10.1111/j.1467-6494.1992.tb00976.x

McAdams, D. P. (2008). "Personal narratives and the life story," in Handbook of Personality: Theory and Research, 3rd Edn., eds O. John, R. Robins, and L. A. Pervin (New York, NY: Guilford Press), 241-261.

Mounier, E. (1952). Personalism. Notre Dame: University of Notre Dame Press.

Nilsson, A. (2013). The Psychology of Worldviews: Toward a Non-Reductive Science of Personality. Doctoral dissertation, Lund University, Sweden. Available online at: http://lup.lub.lu.se/record/ 3738772/file/3738786.pdf (Accessed July 28, 2014).

Nilsson, A. (2014). Personality psychology as the integrative science of traits and worldviews. New Ideas Psychol. 32, 18-32. doi: 10.1016/j.newideapsych.2013.04.008

Peterson, C., and Seligman, M. (2004). Character Strengths and Virtues: A Handbook and Classification. New York, NY: Oxford University Press.

Pettersson, E., and Turkheimer, E. (2010). Item selection, evaluation, and simple structure in personality data. J. Res. Pers. 44, 407-420. doi: 10.1016/j.jrp.2010.03.002

Pippin, R. B. (1989). Hegels Idealism: the Satisfactions of Consciousness. New York, NY: Cambridge University Press. doi: 10.1017/CBO9780511621109

Popper, K. (1959). The Logic of Scientific Discovery. London: Hutchinson. 
Quine, W. V. O. (1953). From a Logical Point of View. Harvard University Press.

Schwartz, S. H. (1992). "Universals in the content and structure of values: theoretical advances and empirical tests in 20 countries," in Advances in Experimental Social Psychology, Vol. 2, ed M. Zanna (New York, NY: Academic Press), $1-65$.

Searle, J. R. (1983). Intentionality: An Essay in the Philosophy of Mind. Cambridge: Cambridge University Press.

Searle, J. R. (1992). The Rediscovery of the Mind. London: MIT Press.

Searle, J. R. (1997). The Mystery of Consciousness. New York, NY: The New York Review of Books.

Stenger, V. J. (1993). The myth of quantum consciousness. Humanist 53, 13-15.

Stern, W. (1938). General Psychology, from the Personalistic Standpoint. (H. D. Spoerl, Transl.).
New York, NY: The Macmillan Company. doi: 10.1037/11642-000

Tomkins, S. S. (1965). "Affect and the psychology of knowledge," in Affect, Cognition, and Personality, eds S. S. Tomkins and C. E. Izard (New York, NY: Springer), 72-97.

Tomkins, S. S. (1979). "Script theory: differential magnification of affects," in Nebraska Symposium on Motivation: Vol. 26, Human emotion, eds H. E. Howe and R. E. Dienstbier (Lincoln: University of Nebraska Press), 201-236.

Wong, P. T. P. (2012). The Human Quest for Meaning: Theory, Research, and Applications, 2nd Edn. New York, NY: Routledge.

Conflict of Interest Statement: The author declares that the research was conducted in the absence of any commercial or financial relationships that could be construed as a potential conflict of interest.
Received: 21 May 2014; accepted: 12 August 2014; published online: 28 August 2014.

Citation: Nilsson A (2014) A non-reductive science of personality, character, and well-being must take the person's worldview into account. Front. Psychol. 5:961. doi: 10.3389/fpsyg.2014.00961

This article was submitted to Personality and Social Psychology, a section of the journal Frontiers in Psychology.

Copyright (1) 2014 Nilsson. This is an open-access article distributed under the terms of the Creative Commons Attribution License (CC BY). The use, distribution or reproduction in other forums is permitted, provided the original author(s) or licensor are credited and that the original publication in this journal is cited, in accordance with accepted academic practice. No use, distribution or reproduction is permitted which does not comply with these terms. 